\title{
Evaluation of IGF1/IGFBP3 Molar Ratio as an Effective Tool for Assessing the Safety of Growth Hormone Therapy in Small-for- gestational-age, Growth Hormone-Deficient and Prader-Willi Children
}

\author{
(D) Meriem Gaddas ${ }^{1}$, (D) Laurence Périn², (D) Yves Le Bouc 3 \\ 1 University of Sousse, Faculty of Medicine 'Ibn el Jazzar', Department of Physiology and Functional Explorations, Sousse, Tunisia \\ 2Trousseau Hospital, Assistance Publique-Hôpitaux de Paris, Department of Pediatric Endocrinology, Paris, France \\ 3Sorbonne Université, INSERM, Centre de Recherche St-Antoine UMR S938, Assistance Publique-Hôpitaux de Paris, Trousseau Hospital, \\ Department of Pediatric Endocrinology, Paris, France
}

What is already known on this topic?

Growth hormone $(\mathrm{GH})$ therapy is widely used, but concerns have been raised that it might increase cancer and cardiovascular risks.

\section{What this study adds?}

This study provides support for the use of IGF1/IGFBP3 molar ratio as a tool for assessing the safety of the therapeutic adaptation of GH therapy in children.

\begin{abstract}
Objective: IGF1 concentration is the most widely used parameter for the monitoring and therapeutic adaptation of recombinant human growth hormone $(\mathrm{rGH})$ treatment. However, more than half the variation of the therapeutic response is accounted for by variability in the serum concentrations of IGF1 and IGFBP3. We therefore compared the use of IGF1/IGFBP3 molar ratio with that of IGF1 concentration alone.

Methods: We selected 92 children on rGH for this study and assigned them to three groups on the basis of growth deficiency etiology: small for gestational age (SGA), GH deficiency (GHD) and Prader-Willi syndrome (PWS). Plasma IGF1 and IGFBP3 concentrations and their molar ratio were determined.

Results: Before rGH treatment, mean IGF1/IGFBP3 molar ratio in the SGA, GHD and PWS groups was $0.14 \pm 0.04,0.07 \pm 0.01$ and $0.12 \pm 0.02$, respectively. After the initiation of $\mathrm{rGH}$ treatment, these averages were $0.19 \pm 0.07,0.20 \pm 0.08$ and $0.19 \pm 0.09$, within the normal range for most children, even at puberty and despite some significant increases in serum IGF1 levels.

Conclusion: We consider IGF1/IGFBP3 molar ratio to be a useful additional parameter for assessing therapeutic safety in patients on $\mathrm{rGH}$, and for maintaning the values within the normal range for age and pubertal stage.

Keywords: GH therapy, IGF1/IGFBP3 molar ratio, growth hormone deficiency, small for gestational age, Prader-Willi syndrome
\end{abstract}

\section{Introduction}

IGF1 serum concentration remains the most widely used parameter for the monitoring and adjustment of recombinant human growth hormone (rGH) treatment (1). However, more than $58 \%$ of the variation in the therapeutic response to rGH over the first year of treatment in children can be explained by the variability of serum concentrations of IGF1 and IGFBP3 (2).

In current practice, due to technical difficulties,total IGF1 concentration is usually measured without determination of free IGF1 levels (2). Free IGF1 can be assumed as the 
bioactive form, but it is in equilibrium with bound IGF1 engaged in large and small complexes, according to the mass action law; almost $99 \%$ of the serum IGF1 is engaged in such large and small complexes (1).

It is therefore impossible to determine tissue bioavailability and, thus, therapeutic efficacy or safety of IGF1 from IGF1 or IGFBP3 assays alone. Furthermore, a lack of correlation between daily GH secretion and total IGF1 concentration has been reported in some cases (1). This situation may be due to the presence of various polymorphisms affecting sensitivity to GH, which may differ for IGF1 and IGFBP3. It should also be noted that IGF1 concentrations vary considerably among individuals $(3,4)$.

Finally, the dynamics of serum concentrations of IGF1 and its carrier protein, IGFBP3, remain unclear in patients on $\mathrm{rGH}$ treatment, and conflicting results have often been obtained (5). Moreover, high IGF1 concentrations have been implicated in cancer, whereas IGFBP3 has a protective effect (6). We therefore believe that determining the bioavailability of IGF1 by calculating the IGF1/IGFBP3 molar ratio would provide more information about the safety of rGH treatment than the use of total IGF1 assays alone.

\section{Methods}

This retrospective study was performed at the Hormonology and Functional Endocrine Explorations Laboratory of Armand Trousseau Hospital in Paris. We selected, from our database, 92 children on $\mathrm{rGH}$ treatment followed at our outpatient clinics. These children were assigned to three groups on the basis of the etiology of their growth deficiency: 20 children who were small for gestational age (SGA group), 61 children with GH deficiency (GHD group), and 11 children with Prader-Willi syndrome (PWS group) (see Table 1A). Retrospective study of the patients' files covered the period 2011-2017 and the clinical and biological data under treatment corresponded to the period March 2016-March 2017. The duration of the treatments and the follow-up of the patients varied from two to seven years.

The doses of rGH administered were as follows: $34.96 \pm 14.35$ $\mu \mathrm{g} / \mathrm{kg} /$ day for the SGA group, $25.56 \pm 10.01 \mu \mathrm{g} / \mathrm{kg} /$ day for the GHD group and $21.67 \pm 8.45 \mu \mathrm{g} / \mathrm{kg} /$ day for the PWS group. No adverse events attributable to $\mathrm{rGH}$ were reported in these children during follow-up.

Clinical [etiological diagnosis, height, weight, body mass index (BMI), rGH dose] and biological (IGF1, IGFBP3, insulin, fasting glycemia, lipid status, HbA1c) data were collected by consulting the patient's medical records. Clinical parameters (height, weight and BMI) were standardized relative to the corresponding national reference ranges (7). IGF1 and IGFBP3 are expressed as Z-standard deviation (SD) scores (SDS) adjusted for age, sex and pubertal stage. Baseline clinical and biological characteristics were obtained for each of the etiological groups (Table $1 \mathrm{~A}$ ). National ethics and confidentiality rules were respected, in accordance with the legislation in force for retrospective studies of cohort files.

The IGF1 and IGFBP3 assays were performed with the IDS-Isys system (Immunodiagnostic Systems, 153 Avenue d'Italie, 75013 Paris, France), in an automated procedure based on ELISA with detection by chemiluminescence. The IDS-Isys device was calibrated according to the new World Health Organization international standard for IGF1 NIBSC $02 / 254$, in accordance with the recommendations of the Growth Hormone Research Society and the International IGF Research Society $(8,9,10,11)$.

Serum IGF1 and IGFBP3 concentrations were interpreted by comparison with the reference intervals established specifically for this iSYS device by Bidlingmaier et al (10) for IGF1 and by Friedrich et al (11) for IGFBP3.

The IGF1/IGFBP3 molar ratio was calculated according to the formula as previously described $(11,12)$ : $[\operatorname{IGF} 1(\mathrm{ng} / \mathrm{mL}) \mathrm{x}$ 0.13] / [IGFBP-3 (ng/mL) x 0.035]

The reference values used for the interpretation of IGF1/ IGFBP3 molar ratios were based on the data collected in our pediatric functional endocrine exploration department at Trousseau Hospital (see Table 1B). These data come from a control population made up of children who came to consult for follow-up of unrelated pathologies: moderate well-

Table 1. A) Clinical and hormonal characteristics of the children

\begin{tabular}{|c|c|c|c|}
\hline & SGA group & GHD group & PWS group \\
\hline \multicolumn{4}{|l|}{ Clinical data } \\
\hline $\begin{array}{l}\text { Number of } \\
\text { children }\end{array}$ & 20 & 61 & 11 \\
\hline Age (years) & $\begin{array}{l}12.27 \pm 3.50 \\
(5.9-18.9)\end{array}$ & $\begin{array}{l}12.02 \pm 4.09 \\
(1.4-18.9)\end{array}$ & $\begin{array}{l}10.88 \pm 5.23 \\
(1.4-16.4)\end{array}$ \\
\hline Boys/girls & $15 / 5$ & $41 / 20$ & $6 / 5$ \\
\hline Weight (SDS) & $-0.71 \pm 2.52$ & $0.83 \pm 2.46$ & $7.97 \pm 3.20$ \\
\hline Height (SDS) & $-1.46 \pm 0.87$ & $-0.97 \pm 1.16$ & $-0.76 \pm 1.53$ \\
\hline BMI (SDS) & $0.57 \pm 2.44$ & $0.58 \pm 1.88$ & $9.44 \pm 2.87$ \\
\hline \multicolumn{4}{|l|}{ Biological data } \\
\hline $\begin{array}{l}\text { IGF1/IGFBP3 ratio } \\
\text { before rGH }\end{array}$ & $0.14 \pm 0.04$ & $0.07 \pm 0.01$ & $0.12 \pm 0.02$ \\
\hline $\begin{array}{l}\text { IGF1/IGFBP3 ratio } \\
\text { after } r G H\end{array}$ & $0.19 \pm 0.07$ & $0.20 \pm 0.08$ & $0.19 \pm 0.09$ \\
\hline \multicolumn{4}{|c|}{$\begin{array}{l}\text { SDS: standard deviation scores, rGH: recombinant human growth hormone, } \\
\text { SGA: small for gestational age, GHD: growth hormone deficiency, PWS: } \\
\text { Prader-Willi syndrome, BMI: body mass index }\end{array}$} \\
\hline
\end{tabular}


balanced asthma follow-up under inhaled corticosteroid, isolated hypospadias or testicular ectopy, moderate growth retardation of around -1 SDS and treated hypothyroid children stably euthyroid. These data were obtained from control children of different ages and pubertal stages and were comparable, as described by Friedrich et al (11), for IGF1/IGFBP3 molar ratio determinations.

The study design (retrospective analysis of the data) was approved by the Ethical Committee of Trousseau Hospital without an approval number. Informed consent has been obtained from the parents after full explanation of the purpose and nature of all procedures used.

\section{Statistical Analysis}

Prism 6 Software (GraphPad Software, La Jolla, CA, USA) was used for all statistical analyses. ANOVA was performed to compare quantitative and qualitative variables between groups. A paired t-test was performed to compare qualitative variables between groups. Differences were considered significant if the $p$ value was $<0.05$. A correlation analysis (Spearman) was carried out between the individual values of the three ratios and those of quantitative parameters.

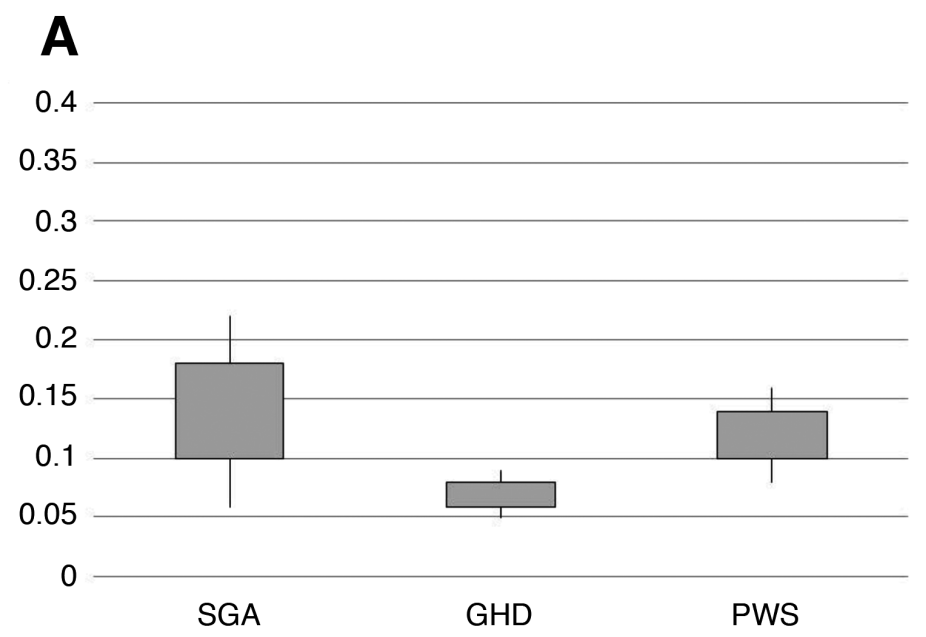

\section{Results}

Before $\mathrm{rGH}$ treatment, the mean $\pm \mathrm{SD}$ molar ratio was $0.14 \pm 0.04$ (range: $0.09-0.23$ ) in the SGA group, $0.07 \pm 0.01$ (range: $0.06-0.08$ ) in the GHD group and $0.12 \pm 0.02$ (range: 0.10-0.14) in the PWS group (Figure 1A).

The IGF1/IGFBP3 molar ratio values of the various groups in this study improved on rGH treatment, reaching values in the normal range for healthy children of the same age (Table 1A, 1B). Mean \pm SD IGF1/IGFBP3 molar ratio on $\mathrm{rGH}$ treatment was $0.19 \pm 0.07$ (range: 0.12-0.35) for the SGA group, $0.20 \pm 0.08$ (range 0.04-0.36) for the GHD group and $0.19 \pm 0.09$ (range: 0.04-0.32) for the PWS group (Figure $1 \mathrm{~B})$. There was a positive correlation between the individual dose values of $\mathrm{rGH}$ and the individual values of the whole ratio $(p=0.03)$. However the correlation between lownormal and high ratio groups and growth increments was not significant $(p=0.15)$, probably due to the heterogeneity of age and duration of treatment.

In the SGA group (Figure 2), two children with high serum IGF1 concentrations ( $>+2$ SDS) had normal IGF1/IGFBP3 molar ratios, because their IGFBP3 levels were also high $(>+2 \mathrm{SDS})$.

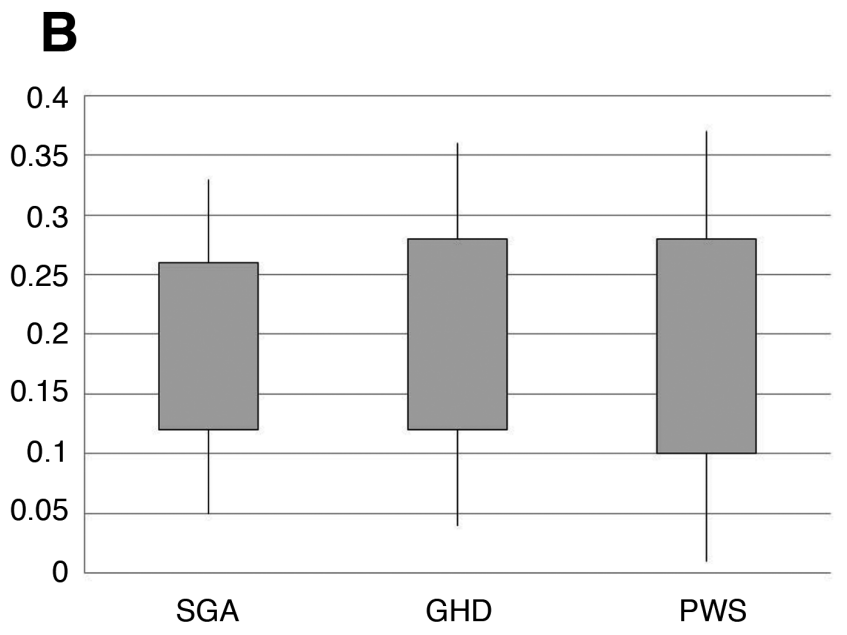

Figure 1. Distribution of IGF1/IGFBP3 ratio in the three groups before (A) and after (B) recombinant human growth hormone treatment. Rectangles represent values between +1 and -1 standard deviation scores (SDS) and bars represent SDS values SGA: small for gestational age, GHD: growth hormone deficiency, PWS: Prader-Willi syndrome

\begin{tabular}{llllll}
\hline \multicolumn{7}{l}{ Table 1. B) Change in IGF1/IGFBP3 molar ratio in control children by age and pubertal stage } & \\
\hline Samples, $\mathrm{n}$ & 23 & 18 & 15 & 16 & 18 \\
Puberty stage & & & & $\mathrm{P} 1$ & $\mathrm{P} 2-\mathrm{P} 5$ \\
Age (years) & $0-4$ & $>4-8$ & $>8-10$ & $9-13$ & $11-17$ \\
Mean IGF1/IGFBP3 molar ratio & 0.10 & 0.12 & 0.14 & 0.16 & 0.27 \\
Standard deviation & 0.05 & 0.03 & 0.03 & 0.05 & 0.06 \\
Range & $0.03-0.24$ & $0.08-0.18$ & $0.10-0.21$ & $0.10-0.20$ & $0.19-0.39$ \\
\hline
\end{tabular}


In the GHD group, an analysis of IGF1 concentration according to age and pubertal stage after treatment revealed that $13 \%$ of children had IGF1 concentrations $>+2$ SDS, particularly during the pubertal period. However, when IGFBP3 levels were also taken into account, the IGF1/ IGFBP3 molar ratios of these children were found to be in the normal range for age and pubertal stage (Figure 3, Table
1B). We also found one five-year-old child with a normal IGF1 concentration but a very high molar ratio ( $>+2$ SDS), because of a very low IGFBP3 concentration (<-2 SDS), requiring therapeutic adaptation (Figure 3).

In the group of treated children with PWS, we identified one case in which serum IGF1 concentration was normal but the IGF1/IGFBP3 molar ratio was low due to a high
A

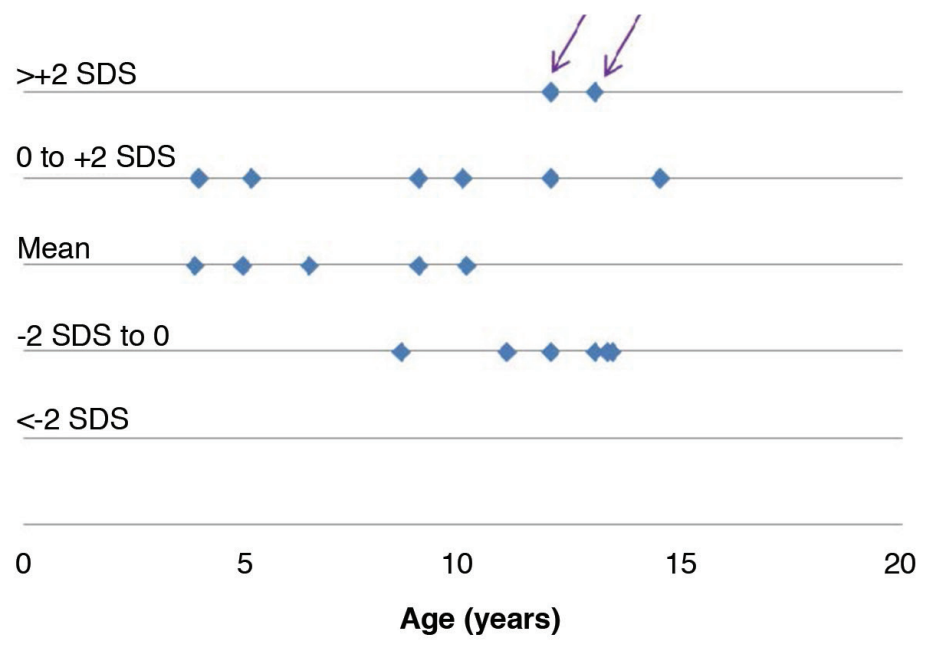

B

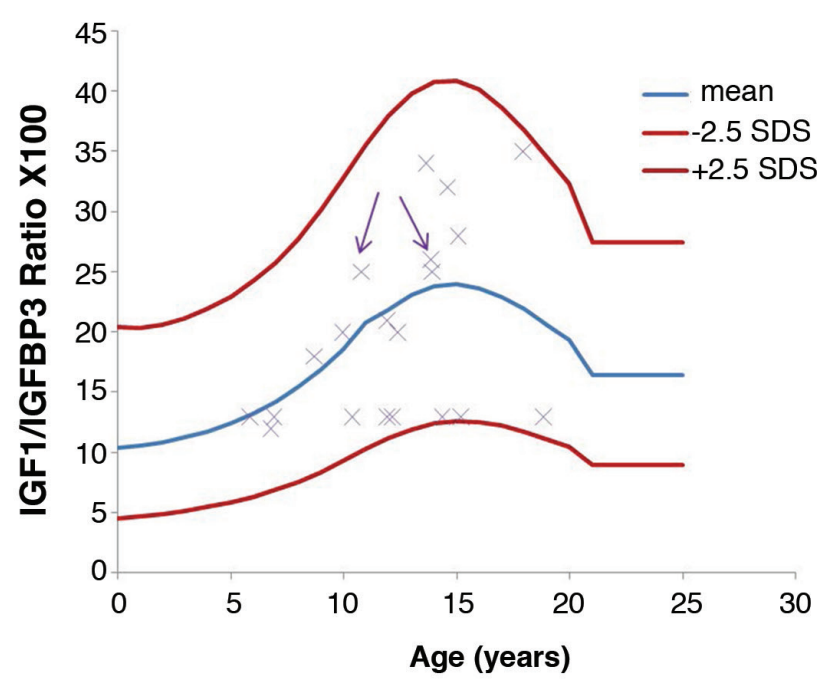

Figure 2. Distribution of IGF1 concentration (A) and IGF1/IGFBP3 molar ratio (B), in small for gestational age (SGA) children during growth hormone treatment. The IGF1 values have been distributed according to the standard deviation scores (SDS) intervals established by Bidlingmaier et al (10). In the SGA group, two children had IGF1 concentrations > + 2 SDS, but IGF1/ IGFBP3 molar ratios in the normal range (arrows)

A

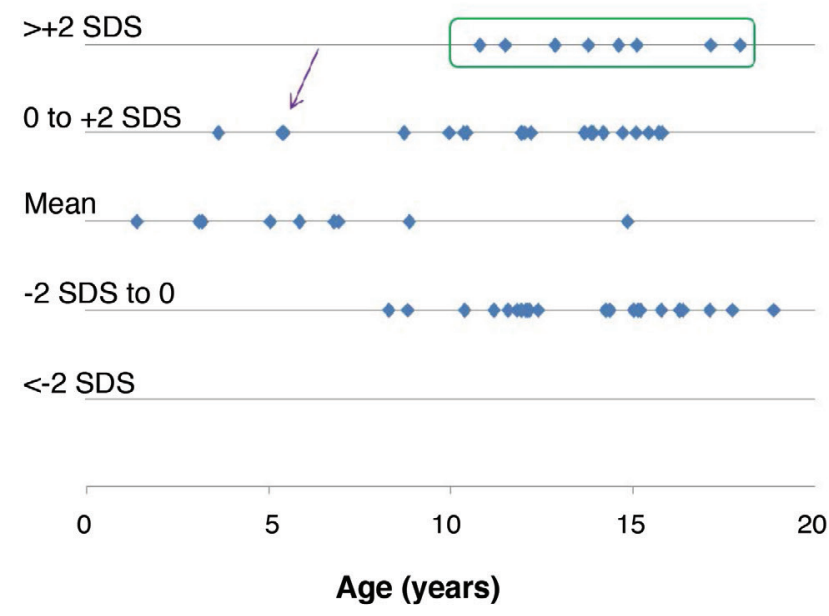

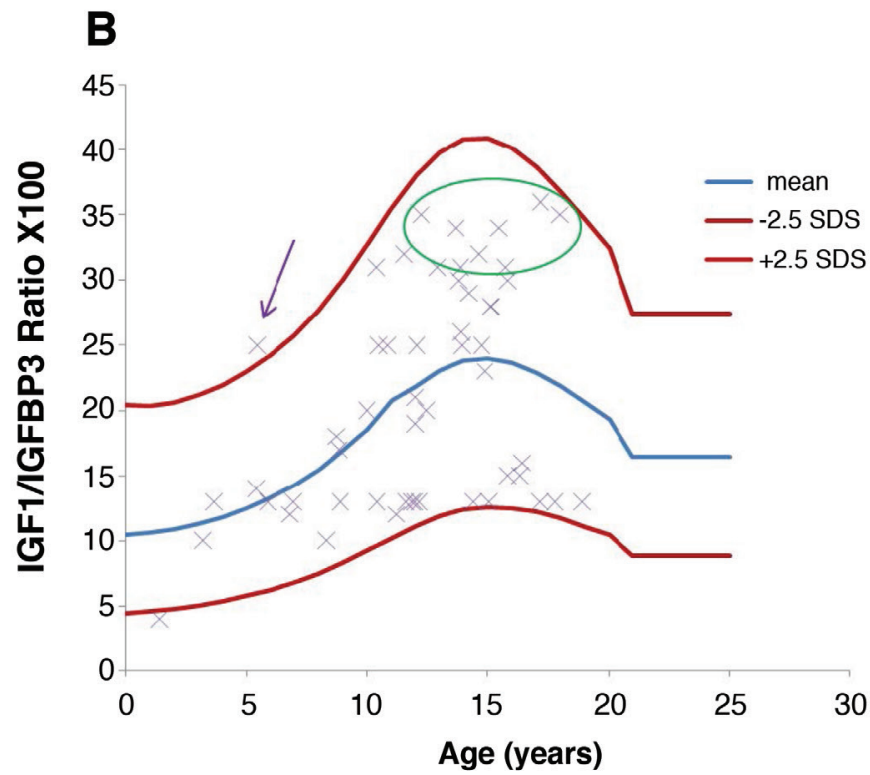

Figure 3. Distribution of IGF1 (A) and IGF1/IGFBP3 molar ratio (B), in children with growth hormone deficiency (GHD) during $\mathrm{GH}$ treatment. In the GHD group, eight children had IGF1 concentrations $>+2$ SDS (circled cases), but IGF1/IGFBP3 molar ratios in the reference range. Conversely, one five-year-old child had an IGF1 concentrations in the reference range but a very high molar ratio due to a very low IGFBP3 concentration $(<-2$ SDS; arrow) 
IGFBP3 concentration ( +2 SDS), one case in which serum IGF1 concentration was normal but the molar ratio was high due to a very low IGFBP3 concentration ( $<-2$ SDS) and one case in which serum IGF1 concentration was high but the molar ratio was low, due to a high IGFBP3 concentration (Figure 4).

We then assessed the clinical, biochemical and metabolic characteristics of children on rGH with IGF1/IGFBP3 molar
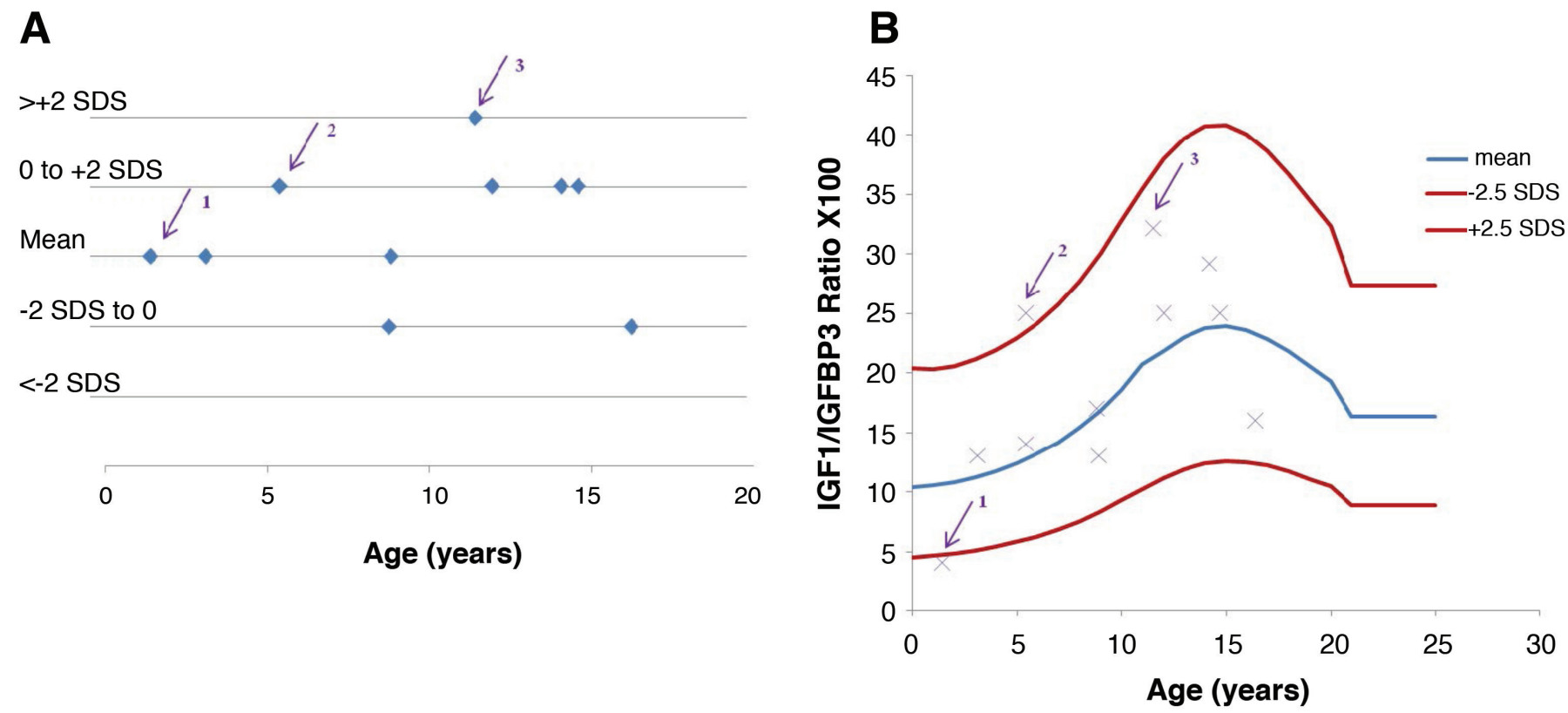

Figure 4. Distribution of IGF1 (A) and IGF1/IGFBP3 molar ratio (B), in children with Prader-Willi syndrome (PWS) during growth hormone $(\mathrm{GH})$ treatment. In the PWS group, three children had discrepancies between serum IGF1 levels [expressed in standard deviation scores (SDS)] and IGF1/IGFBP3 molar ratio. 1 st case (arrow 1): 1.4-year-old child with PWS and an IGF1 concentration in the normal range (expressed in SDS) but a low molar ratio (due to very high IGFBP3 concentration $>+2$ SDS). 2nd case (arrow 2): 5.4-year-old child with PWS and an IGF1 concentration in the normal range (expressed in SDS) but a high IGF1/IGFBP3 molar ratio (due to low IGFBP3 concentration). $3^{\text {rd }}$ case (arrow 3): 11.4-year-old child with a high IGF1 concentration (expressed in SDS) and an IGF1/IGFBP3 molar ratio in the reference range (IGFBP3 concentration towards the upper end of the reference range)

Table 2. Clinical and metabolic characteristics of children on recombinant human growth hormone with molar ratios higher or lower than the normal range

\begin{tabular}{|c|c|c|c|c|c|c|c|c|}
\hline & \multirow[b]{2}{*}{$\begin{array}{l}\text { Low ratio } \\
(\mathrm{n}=41)\end{array}$} & \multirow[b]{2}{*}{$\begin{array}{l}\text { Normal ratio } \\
(\mathrm{n}=33)\end{array}$} & \multirow[b]{2}{*}{$\begin{array}{l}\text { High ratio } \\
(n=18)\end{array}$} & \multicolumn{2}{|c|}{ ANOVA } & \multicolumn{3}{|c|}{ Post-hoc ANOVA p values } \\
\hline & & & & F-value & $\mathrm{p}$ value & $\begin{array}{l}\text { Low vs } \\
\text { normal }\end{array}$ & $\begin{array}{l}\text { Low vs } \\
\text { high }\end{array}$ & $\begin{array}{l}\text { Normal } \\
\text { vs high }\end{array}$ \\
\hline Ratio (post rGH) & $0.12 \pm 0.02$ & $0.24 \pm 0.03$ & $0.32 \pm 0.02$ & 467.56 & $<0.0001$ & $<0.0001$ & $<0.0001$ & $<0.0001$ \\
\hline Age (years) & $9.92 \pm 4.77$ & $12.61 \pm 2.85$ & $14.19 \pm 2.01$ & 10.00 & 0.0001 & 0.0051 & 0.0004 & 0.0379 \\
\hline BMI (SDS) & $0.41 \pm 1.63$ & $0.31 \pm 1.01$ & $0.18 \pm 1.30$ & 0.16 & 0.84 & 0.7661 & 0.6139 & 0.7267 \\
\hline Height (SDS) & $-0.85 \pm 1.10$ & $-0.95 \pm 1.41$ & $-1.38 \pm 0.99$ & 1.19 & 0.30 & 0.7228 & 0.0933 & 0.2828 \\
\hline rGH dose ( $\mu \mathrm{g} / \mathrm{kg} /$ day) & $24.99 \pm 9.46$ & $28.33 \pm 9.82$ & $39.67 \pm 17.20$ & 8.82 & 0.0003 & 0.1989 & 0.0002 & 0.0153 \\
\hline Insulin (mIU/L) & $5.47 \pm 3.30$ & $5.85 \pm 3.15$ & $9.77 \pm 4.17$ & 7.25 & 0.0017 & 0.7450 & 0.0011 & 0.0125 \\
\hline $\operatorname{HbA1c}(\%)$ & $5.33 \pm 0.36$ & $5.07 \pm 0.28$ & $5.40 \pm 0.34$ & 1.87 & 0.17 & 0.0976 & 0.7801 & 0.1334 \\
\hline Fasting glycemia (mmol/L) & $4.72 \pm 1.30$ & $4.77 \pm 0.25$ & $4.80 \pm 0.29$ & 0.03 & 0.96 & 0.8974 & 0.8152 & 0.7744 \\
\hline Total cholesterol (mmol/L) & $4.00 \pm 0.64$ & $4.18 \pm 1.13$ & $3.60 \pm 0.59$ & 1.57 & 0.22 & 0.6327 & 0.1188 & 0.1296 \\
\hline HDL-cholesterol (mmol/L) & $1.63 \pm 0.38$ & $1.66 \pm 0.56$ & $1.46 \pm 0.17$ & 0.65 & 0.52 & 0.9131 & 0.2256 & 0.3279 \\
\hline LDL-cholesterol (mmol/L) & $1.96 \pm 0.49$ & $2.06 \pm 0.75$ & $1.9 \pm 0.47$ & 0.19 & 0.82 & 0.6973 & 0.7734 & 0.5844 \\
\hline Triglycerides (mmol/L) & $0.61 \pm 0.29$ & $0.73 \pm 0.38$ & $0.77 \pm 0.30$ & 0.92 & 0.40 & 0.3828 & 0.1715 & 0.7808 \\
\hline
\end{tabular}


ratios inappropriate for age, either higher $(>+2 \mathrm{SDS})$ or lower $(<-2$ SDS) than the normal range (Table 2).

The three study groups were heterogeneous, differing significantly in terms of age and IGF/IGFBP3 molar ratio increases with age. We also noted that both the doses of rGH administered and insulinemia were significantly higher in children with a high molar ratio than in those with a low or normal molar ratio (Table 2). Moreover there was a positive correlation between individual values of insulinemia and the individual values of the whole ratio $(p=0.01)$.

For the other metabolic parameters considered (fasting glycemia, lipid status, HbA1c), we found no significant differences between children with low, normal and high IGF1/IGFBP3 molar ratios (Table 2).

\section{Discussion}

During rGH treatment, increases in the serum concentrations of IGF1 and IGFBP3 are expected because these factors are known to be GH-dependent and to have low basal levels in patients with GHD $(13,14)$.

rGH modifies the distribution of circulating IGF1 between ternary complexes (IGF1/IGFBP3/ALS), binary complexes (IGF1/IGFBP3) and free forms (13). It simultaneously stimulates the production of all three forms, but this effect is stronger for ternary and binary complexes than for free forms (13). The concentration of the bioactive free form of IGF1 does not increase on treatment, even if the total amount of IGF1 increases (13). Thus, rGH increases the levels of IGF1 and IGFBP3 in a heterogeneous, dosedependent $(5,15)$ manner that differs between individuals $(12,13)$.

In this context, IGFBP3 has been reported to be less sensitive to $\mathrm{rGH}$ than IGF1 in adults, with the increase in the concentrations of the former responding less quickly than the latter following rGH therapy (15). This difference results from the hepatic synthesis of IGFBP3s being under the control not only of GH, but also of IGF1s (15). Ranke et al (5) showed that, on rGH treatment, the IGF1dependent increase in IGFBP3 concentration occurs in two phases: an initial linear phase, followed by a saturation phase in which IGFBP3 concentrations reach a plateau, despite further increases in IGF1 concentration. This would account for the increase in IGF1/IGFBP3 ratio at high doses of rGH. This phenomenon also highlights inequalities in the ability of the liver to synthesize IGF1 (synthesized by hepatocytes) and IGFBP3 (synthesized by Kupffer cells) (16). Thus, at high doses of rGH, serum IGF1 concentration may increase more strongly and more rapidly than IGFBP3 concentration, resulting in an increase in tissue-bioavailable IGF1 concentration (15).

Serum IGF1 and IGFBP3 disorders are known to be associated with a shorter lifespan in humans (17) due to the associated high risk of cardiovascular $(18,19,20)$ and neoplastic comorbidity (21). Indeed, high concentrations of IGF1, a mitogen and anti-apoptotic hormone, have been implicated in the occurrence of various types of cancer $(22,23)$, particularly when associated with low levels of IGFBP3 $(24,25,26)$. In contrast, high serum IGFBP3 concentrations appear to have protective effects against cancer (6) but have been shown to be associated with diabetes, high triglyceride levels and hypertension, whereas low IGFBP3 levels are associated with a large waist circumference and low levels of HDL cholesterol (27).

These findings reflect the U-shaped correlation curve obtained for the relationship between serum IGF1 and IGFBP3 concentrations initially described by the histograms of Juul et al (28) and subsequently confirmed by the "quartiles" of Park and Cohen (29). Indeed, these representations of the risk of cardiovascular ischemia reported by Juul et al (28) and of cardiovascular and neoplastic risks reported by Park and Cohen (29), highlight the need to take both IGF1 and IGFBP3 into account, because these two parameters have "opposite" biological actions (28) and a dynamic "yin-yang" relationship (29).

We investigated the potential utility of the IGF1/IGFBP3 molar ratio for use in the adaptation of $\mathrm{rGH}$ treatment in three different etiological groups (children SGA, or with GHD or PWS). Indeed, SGA children are characterized by "GH resistance", resulting in a need for higher rGH doses than are used in other children matched for age, sex and puberty stage $(5,30)$. In children, $\mathrm{rGH}$ dose is generally adjusted progressively, on a case-by-case basis (31). There are currently no clear guidelines on the mode of therapeutic adaptation according to the results obtained $(12,29)$. This complicates therapeutic management, because it is considered important to keep IGF1 concentration below +2 SDS, because of the increased risk of cardiovascular diseases and neoplasm (31).

By contrast, almost all PWS children have a somatotropic deficit $(32,33)$, justifying the systematic (34) early initiation of rGH treatment, within the first year of life $(32,33,35)$. Unlike SGA children, children with PWS are particularly "rGHsensitive" and have very high serum IGF1 concentrations (towards and above the upper limit of the normal range) $(33,34,36)$.

For the three pathological entities studied (GHD, SGA and PWS), we found that the determination of IGF1/IGFBP3 
molar ratio was a useful additional tool for the adaptation of rGH treatment with a view to improving safety.

The safety of rGH treatment is generally ensured by monitoring to keep serum IGF1 concentration at values below the +2 SDS threshold for age and pubertal stage (12). Our results indicate that there may be discrepancies between total IGF1 concentration and IGF1/IGFBP3 molar ratio with a potential impact on the safety of rGH treatment. The use of this ratio made it possible to optimize rGH administration so as to minimize the risk of adverse effects, particular those of a metabolic, cardiovascular or neoplastic nature $(17,28,37)$.

Calculation of the IGF1/IGFBP3 molar ratio is, thus, a potentially useful additional tool because this ratio does not necessarily vary with increases in IGF1 concentration and it takes into account the variation of serum IGFBP3 levels (12).

We were able to determine approximate values for IGF1/ IGFBP3 molar ratio before and after the initiation of $\mathrm{rGH}$ treatment in children SGA or with GHD or PWS. We found that the mean ratio increased after the initiation of $\mathrm{rGH}$ treatment in all groups, but that it remained within the reference range for age and pubertal stage in most children. Our values were consistent with those reported in previous studies. Romer et al (38) reported a low ratio in patients with GHD $(0.13 \pm 0.07)$ before $\mathrm{rGH}$, with a sharp increase to more than $0.32 \pm 0.07$ after treatment initiation. Our results are also consistent with those of Cabrol et al (12), who reported a mean molar ratio before treatment of 0.14 (range: 0.10 to 0.27 ) in children SGA, increasing to 0.19 (range: 0.15 to 0.23 ) after treatment.

Finally, on $\mathrm{rGH}$ treatment at the doses currently recommended, the IGF1/IGFBP3 molar ratio remained within the normal range for age and sex, even during puberty. We also found that, in children treated with rGH, significant increases in serum IGF1 levels were sometimes associated with IGF1/IGFBP3 molar ratios within the normal range for age and pubertal stage. This suggests that, even in cases of high IGF1 concentration, the action of this molecule is counteracted by an adaptation of IGFBP3 levels, decreasing IGF1 bioavailability.

\section{Study Limitations}

This study included a small number of subjects and our results therefore require confirmation in a larger cohort.

\section{Conclusion}

We consider IGF1/IGFBP3 molar ratio to be a useful additional parameter for assessments of treatment safety and for the adjustment of rGH treatment. The goal would be to maintain this ratio within the normal reference range for age and pubertal stage.

\section{Ethics}

Ethics Committee Approval: All procedures involving human participants in this study were performed in accordance with the French national rules for ethics and confidentiality, also in accordance with current legislation for retrospective non-interventional studies of cohort files.

Informed Consent: All clinical data and biological analyses were performed as part of routine follow-up, without the collection of additional samples. Under French law, no specific consent for this anonymous study was therefore required. Concerning the ratio reference values of the control children, the families gave their consent to use the remains of the blood samples to this purpose.

Peer-review: Externally and internally peer-reviewed.

\section{Authorship Contribution}

Medical Practices: Yves Le Bouc, Concept: Yves Le Bouc, Meriem Gaddas, Laurence Périn, Design: Yves Le Bouc, Meriem Gaddas, Laurence Périn, Data Collection or Processing: Yves Le Bouc, Laurence Périn, Analysis or Interpretation: Yves Le Bouc, Meriem Gaddas, Laurence Périn, Literature Search: Meriem Gaddas, Yves Le Bouc, Writing: Meriem Gaddas, Yves Le Bouc.

Financial Disclosure: The authors declared that this study received no financial support.

\section{References}

1. Sizonenko PC, Clayton PE, Cohen P, Hintz RL, Tanaka T, Laron Z. Diagnosis and management of growth hormone deficiency in childhood and adolescence. Part 1: diagnosis of growth hormone deficiency. Growth Horm IGF Res 2001;11:137-165.

2. Hilczer M, Smyczynska J, Lewinski A. Monitoring and optimising of growth hormone $(\mathrm{GH})$ therapy in GH-deficient children - the role of assessment of insulin-like growth factor-I (IGF-I) secretion and IGF-I/ IGF binding protein-3 molar ratio. Med Sci Tech 2006;47:219-223.

3. Berrigan D, Potischman N, Dodd KW, Hursting SD, Lavigne J, Barrett JC, Ballard-Barbash R. Race/ethnic variation in serum levels of IGF-I and IGFBP-3 in US adults. Growth Horm IGF Res 2009;19:146-155. Epub 2008 Sep 21

4. Juul A, Bang P, Hertel NT, Main K, Dalgaard P, Jørgensen K, Müller J, Hall K, Skakkebaek NE. Serum insulin-like growth factor-I in 1030 healthy children, adolescents, and adults: relation to age, sex, stage of puberty, testicular size, and body mass index. J Clin Endocrinol Metab 1994;78:744-752.

5. Ranke MB, Traunecker R, Martin DD, Schweizer R, Schwarze CP, Wollmann HA, Binder G. IGF-I and IGF binding protein-3 levels during initial GH Dosage step-up are indicators of $\mathrm{GH}$ sensitivity in GHdeficient children and short children born small for gestational age. Horm Res 2005;64:68-76. Epub 2005 Aug 19 
6. Renehan AG, Zwahlen M, Minder C, O'Dwyer ST, Shalet SM, Egger M. Insulin-like growth factor (IGF)-I, IGF binding protein-3, and cancer risk: systematic review and meta-regression analysis. Lancet 2004;363:1346-1353.

7. Sempé M, Pédron G, Roy-Pernot MP. Auxologie: Méthode et Séquences. Paris, Théraplix, 1979.

8. Clemmons DR. Consensus statement on the standardization and evaluation of growth hormone and insulin-like growth factor assays. Clin Chem 2011;57:555-559. Epub 2011 Feb 1

9. Burns C, Rigsby P, Moore M, Rafferty B. The first international standard for insulin-like growth factor-1 (IGF-1) for immunoassay: Preparation and calibration in an international collaborative study. Growth Horm IGF Res 2009;19:457-462. Epub 2009 Mar 20

10. Bidlingmaier M, Friedrich N, Emeny RT, Spranger J, Wolthers OD, Roswall J, Körner A, Obermayer-Pietsch B, Hübener C, Dahlgren J, Frystyk J, Pfeiffer AF, Doering A, Bielohuby M, Wallaschofski H, Arafat AM. Reference intervals for insulin-like growth factor-1 (IGF-1) From birth to senescence: results from a multicenter study using a new automated chemiluminescence IGF-1 immunoassay conforming to recent international recommendations. J Clin Endocrinol Metab 2014;99:1712-1721. Epub 2014 Feb 27

11. Friedrich N, Wolthers OD, Arafat AM, Emeny RT, Spranger J, Roswall J, Kratzsch J, Grabe HJ, Hübener C, Pfeiffer AF, Döring A, Bielohuby M, Dahlgren J, Frystyk J, Wallaschofski H, Bidlingmaier M. Age- and sexspecific reference intervals across life span for insulin-like growth factor binding protein 3 (IGFBP-3) and the IGF-I to IGFBP-3 ratio measured by new automated chemiluminescence assays. J Clin Endocrinol Metab 2014;99:1675-1686. Epub 2014 Jan 31

12. Cabrol S, Perin L, Colle M, Coutant R, Jésuran-Perelroizen M, Le Bouc Y, Czernichow P. Evolution of IGF-1 in children born small for gestational age and with growth retardation, treated by growth hormone adapted to IGF-1 levels after 1 year. Horm Res Paediatr 2011;76:419-427. Epub 2011 Dec 8

13. Mandel SH, Moreland E, Rosenfeld RG, Gargosky SE. The effect of GH Therapy on the immunoreactive forms and distribution of IGFBP-3, IGF-I, the acid-labile subunit, and growth rate in GH-deficient children. Endocrine 1997;7:351-360.

14. Cohen P, Germak J, Rogol AD, Weng W, Kappelgaard AM, Rosenfeld RG; American Norditropin Study Group. Variable degree of growth hormone (GH) and insulin-like growth factor (IGF) sensitivity in children with idiopathic short stature compared with GH-deficient patients: evidence from an IGF-based dosing study of short children. J Clin Endocrinol Metab 2010;95:2089-2098. Epub 2010 Mar 5

15. Ghigo E, Aimaretti G, Maccario M, Fanciulli G, Arvat E, Minuto F, Giordano G, Delitala G, Camanni F. Dose-response study of GH effects on circulating IGF-I and IGFBP-3 levels in healthy young men and women. Am J Physiol 1999;276:1009-1013.

16. Uchijima Y, Takenaka A, Takahashi S, Noguchi T. Production of insulinlike growth factors and their binding proteins in primary cultures of rat liver parenchymal and nonparenchymal cells. Biosci Biotechnol Biochem 1995;59:1503-1515.

17. Van Bunderen CC, Van Nieuwpoort IC, Van Schoor NM, Deeg DJ, Lips $\mathrm{P}$, Drent ML. The association of serum insulin-like growth factor-I with mortality, cardiovascular disease, and cancer in the elderly: a population-based study. J Clin Endocrinol Metab 2010;95:4616-4624. Epub 2010 Jul 7

18. Lombardi G, Di Somma C, Grasso LF, Savanelli MC, Colao A, Pivonello $\mathrm{R}$. The cardiovascular system in growth hormone excess and growth hormone deficiency. J Endocrinol Invest 2012;35:1021-1029. Epub 2012 Nov 12
19. Gola M, Bonadonna S, Doga M, Giustina A. Clinical review: growth hormone and cardiovascular risk factors. J Clin Endocrinol Metab 2005; 90:1864-1870. Epub 2004 Dec 7

20. Carel JC, Ecosse E, Landier F, Meguellati-Hakkas D, Kaguelidou F, Rey G, Coste J. Long-term mortality after recombinant growth hormone treatment for isolated growth hormone deficiency or childhood short stature: preliminary report of the French SAGHE Study. J Clin Endocrinol Metab 2012;97:416-425. Epub 2012 Jan 11

21. Swerdlow AJ, Higgins CD, Adlard P, Preece MA. Risk of cancer in patients treated with human pituitary growth hormone in the UK, 1959-85: a cohort study. Lancet 2002;360:273-277.

22. Hankinson SE, Willett WC, Colditz GA, Hunter DJ, Michaud DS, Deroo B, Rosner B, Speizer FE, Pollak M. Circulating concentrations of insulinlike growth factor-I and risk of breast cancer. Lancet 1998;351:13931396.

23. Chokkalingam AP, Pollak M, Fillmore CM, Gao YT, Stanczyk FZ, Deng J, Sesterhenn IA, Mostofi FK, Fears TR, Madigan MP, Ziegler RG, Fraumeni JF Jr, Hsing AW. Insulin-like growth factors and prostate cancer: a population-based case-control study in China. Cancer Epidemiol Biomarkers Prev 2001;10:421-427.

24. Chan JM, Stampfer MJ, Giovannucci E, Gann PH, Ma J, Wilkinson P, Hennekens $\mathrm{CH}$, Pollak M. Plasma insulin-like growth factor-I and prostate cancer risk: a prospective study. Science 1998;279:563-566.

25. Yu H, Spitz MR, Mistry J, Gu J, Hong WK, Wu X. Plasma levels of insulinlike growth factor-I and lung cancer risk: a case-control analysis. J Natl Cancer Inst 1999;91:151-156.

26. Chan JM, Stampfer MJ, Ma J, Gann P, Gaziano JM, Pollak M, Giovannucci E. Insulin-like growth factor-I (IGF-I) and IGF binding protein-3 as predictors of advanced-stage prostate cancer. J Natl Cancer Inst 2002;94:1099-1106

27. Yeap B, Chubb P, Ho K, Setoh J, MacCaul K, Norman P, Jamrozik K, Flicker L. IGF1 and its binding proteins 3 and 1 are differentially associated with metabolic syndrome in older men. Eur J Endocrinol 2010;162:249-257. Epub 2009 Nov 16

28. Juul A, Scheike T, Davidsen M, Gyllenborg J, Jørgensen T. Low serum insulin-like growth factor I is associated with increased risk of ischemic heart disease: a population-based case-control study. Circulation 2002;106:939-944.

29. Park P, Cohen P. The role of insulin-like growth factor I monitoring in growth hormone-treated children. Horm Res 2004;62(Suppl 1):59-65.

30. Ali O, Cohen P. Insulin-like growth factors and their binding proteins in children born small for gestational age: implication for growth hormone therapy. Horm Res 2003;60(Suppl 3):115-123.

31. Jorgensen JO, Flyvbjerg A, Lauritzen T, Alberti KG, Orskov H, Christiansen JS. Dose-response studies with biosynthetic human growth hormone in GH-deficient patients. J Clin Endocrinol Metab 1988;67:36-40.

32. Grugni G, Sartorio A, Crinò A. Growth hormone therapy for PraderWilli syndrome: challenges and solutions. Ther Clin Risk Manag 2016;12:873-881.

33. Diene G, Mimoun E, Feigerlova E, Caula S, Molinas C, Grandjean H, Tauber M; French Reference Centre for PWS. Endocrine disorders in children with Prader-Willi syndrome--data from 142 children of the French database. Horm Res Paediatr 2010;74:121-128. Epub 2010 Apr 15

34. Deal CL, Tony M, Höybye C, Allen DB, Tauber M, Christiansen JS; 2011 Growth Hormone in Prader-Willi Syndrome Clinical Care Guidelines Workshop Participants. Growth Hormone Research Society Workshop Summary: Consensus Guidelines for Recombinant Human Growth Hormone Therapy in Prader-Willi Syndrome. J Clin Endocrinol Metab 2013;98:1072-1087. Epub 2013 Mar 29 
35. Bar C, Diene G, Molinas C, Bieth E, Casper C, Tauber M. Early diagnosis and care is achieved but should be improved in infants with PraderWilli syndrome. Orphanet J Rare Dis 2017;12:118.

36. Bakker NE, Van Doorn J, Renes JS, Donker GH, Hokken-Koelega AC. IGF1 levels, complex formation, and IGF bioactivity in growth hormonetreated children with Prader-Willi Syndrome. J Clin Endocrinol Metab 2015;100:3041-3049. Epub 2015 May 29

37. Swerdlow AJ, Cooke R, Beckers D, Borgström B, Butler G, Carel JC, Cianfarani S, Clayton P, Coste J, Deodati A, Ecosse E, Gausche R,
Giacomozzi C, Hokken-Koelega ACS, Khan AJ, Kiess W, Kuehni CE, Mullis PE, Pfaffle R, Sävendahl L, Sommer G, Thomas M, Tidblad A, Tollerfield S, Van Eycken L, Zandwijken GRJ. Cancer risks in patients treated with growth hormone in childhood: the SAGHE European cohort study. J Clin Endocrinol Metab 2017;102:1661-1672.

38. Romer T, Saenger P, Peter F, Walczak M, Le Bouc Y, Khan-Boluki J, Berghout A. Seven years of safety and efficacy of the recombinant human growth hormone omnitrope in the treatment of growth hormone deficient children: results of a phase III study. Horm Res 2009;72:359-369. Epub 2009 Oct 21 